\title{
UTILITY OF ALBUMIN CREATININE RATIO (ACR) IN MONITORING DIABETIC RETINOPATHY AND NEPHROPATHY
}

\author{
Muhammad Aneeq Haroon, Haroon Javiad*, Zujaja Hina Haroon**, Usama Bin Khalid**, Afshan Bibi**, Azka Haroon** \\ Foundation University Medical College, Rawalpindi Pakistan, ${ }^{*}$ HITEC Institute of Medical Sciences, Taxila/National University of Medical Sciences (NUMS) \\ Pakistan, ${ }^{* *}$ Armed Forces Institute of Pathology/National University of Medical Sciences (NUMS) Rawalpindi Pakistan
}

\begin{abstract}
Objective: To evaluate Albumin Creatinine Ratio (ACR) as a screening marker for detection of early diabetic retinopathy in parallel with diabetic nephropathy.

Study Design: Comparative cross sectional study.

Place and Duration of Study: Department of Ophthalmology and Chemical Pathology \& Endocrinology, Combined Military Hospital, Multan, from Jul 2017 to Jul 2019.

Methodology: A total of 386 diagnosed patients of type II diabetes mellitus who reported for follow up and monitoring in Combined Military Hospital Multan, underwent initial screening with urine dip strip, if protein positive patients were excluded if negative patients were included in the study. Urinary albumin creatinine ratio was calculated as $\mathrm{mg} / \mathrm{mmol}$ of creatinine. For staging of diabetic retinopathy; participants underwent ocular examinations. Pearson correlation was performed and ROC was constructed at different cut-offs.

Results: Out of the $386(100 \%)$ patients with type II diabetes $284(74 \%)$ had albumin creatinine ratio $<3 \mathrm{mg} / \mathrm{mmol}$ and 102 $(26 \%)$ had micro albuminuria i.e. albumin creatinine ratio $3-30 \mathrm{mg} / \mathrm{mmol}$. Among normal albumin uric cases (284) only 52 $(18 \%)$ patients had mild to moderate non-proliferative diabetic retinopathy.

Conclusion: Albumin creatinine ratio is associated with severity of diabetic retinopathy. Since diabetic retinopathy stages have been identified in normal albumin uric range, there is need to determine a definite cut off value $(<3 \mathrm{mg} / \mathrm{mmol})$ of ACR for using it as a screening marker for diabetic retinopathy.
\end{abstract}

Keywords: Albumin to-creatinine ratio ACR, Diabetic retinopathy, Type II diabetes mellitus.

This is an Open Access article distributed under the terms of the Creative Commons Attribution License (https://creativecommons.org/licenses/by-nc/4.0/), which permits unrestricted use, distribution, and reproduction in any medium, provided the original work is properly cited.

\section{INTRODUCTION}

Diabetes mellitus (DM) is a chronic metabolic disease characterized by persistent hyperglycemia that leads to serious macrovascular and microvascular complications to the heart, eyes, kidneys, and peripheral nerves. Microalbuminuria is closely associated with diabetic microvascular complications, namely diabetic kidney disease (DKD) and diabetic retinopathy (DR) ${ }^{1}$. In accordance with American Diabetes Association (ADA) and National Kidney Foundation (NKF) guidelines, albumin-to-creatinine ratio (ACR) is used as a criterion for defining albuminuria ${ }^{2,3}$. Recently, the classification of CKD has included ACR in the staging of the disease; normal: $<3 \mathrm{mg} / \mathrm{mmol}$, microalbuminuria: $3-29 \mathrm{mg} / \mathrm{mmol}$, Macroalbuminuria: $\geq 30 \mathrm{mg} / \mathrm{mmol}$, in accordance to Kidney Disease: Improving Global Outcomes (KDIGO) clinica practice guidelines. Kidney damage is assessed by albuminuria as a marker for glomerular function. Chronic kidney disease (CKD) in patients of DM is associated with high-normal albuminuria ${ }^{4,5}$, diabetic vascular complications are also

Correspondence: Dr Haroon Javaid, Associate Professor, Department of Ophthalmology, HITEC Taxila, Pakistan

Received: 30 May 2021; revised received: 27 Jul 2021; accepted: 29 Jul 2021 accompanied by albuminuria ${ }^{6}$.

One of the most prevalent chronic complications of diabetes is diabetic retinopathy (DR). This condition is associated with one of the most common causes of new-onset blindness ${ }^{7,8}$. Diabetic retinopathy develops in patients with poor control of diabetes mellitus over time; it is depicted by progressive changes in the capillaries of the retina that result in increased permeability, an impediment to the blood supply of the retina, and intraocular pathology ${ }^{9,10}$. Macular edema develops due to these pathological changes during any stage of the disease. Because this condition is so common among people with diabetes, and if left untreated, it puts a lot of burden on income-poor society.

This study aimed to see if there was a link between ACR and the severity of DR in patients of DM. In addition, we compared DR stages to DKD stages based on ACR to see if albumin creatinine ratio (ACR) may be utilized as a diagnostic screening marker for early diabetic retinopathy, similar to its use in diabetic nephropathy.

\section{METHODOLOGY}

This cross-sectional study was conducted by selecting all patients diagnosed with diabetes mellitus. 
These were the patients who reported for follow-up and monitoring in Combined Military Hospital (CMH) Multan from July 2017 to July 2019. Informed consent was obtained from all the patients. This study was carried out after approval from ethics review committee of the institution. (CMH Mtn ltr no: 6/ Adm/trg/2017 dated 30 April 2017) WHO sample size calculator was used for sample size calculation at $95 \%$ confidence interval and $5 \%$ margin of error taking prevalence of DR 28\% in Pakistan ${ }^{11,12}$, which came out to be 310 . For the collection of data, non-probability consecutive sampling method was employed. Initial screening with urine dipstrip was done and patients with positive dipstrip test for proteins were excluded from the study. However, if protein negative on the urine dip strip, these patients were included in the study. Ten (10) $\mathrm{ml}$ urine was collected in sterile container, urinary albumin was estimated by turbidimetric inhibition immunoassay (TINIA) and creatinine was analysed using modified Jaffe kinetic reaction. Albumin creatinine ratio (ACR) was calculated by using values of urine albumin and creatinine as $\mathrm{mg} / \mathrm{mmol}$. The results were validated by running internal quality control (IQC) program with values plotted on Levy-Jennings (LJ) chart within the same run.

Participants underwent eye examinations, including fundus photography, to determine the stage of diabetic retinopathy. Mild-to-moderate non proliferative diabetic retinopathy (NPDR), severe NPDR, and proliferative diabetic retinopathy (PDR) were the three stages of diabetic retinopathy. Mild to moderate NPDR was defined as microaneurysms and small exudates in less than four quadrants of the retina. Severe NPDR consisted of either microaneurysms and exudates in four quadrants of the retina or venous bleeding in at least two quadrants. PDR was defined as neovascularization in the retina or optic disc. The normal retina was free of all the abnormalities described.

All the data, including biochemical parameters, were evaluated using computer software. Frequency, percentages, mean, and SD were determined as descriptive statistics. Stratification of data was done to reduce bias and to find out associations between groups.
The K-S test assessed the normality of data. Chi-square and t-test were employed to find any significant difference between the variables. For differences among grades of diabetic retinopathy, an analysis of variance (ANOVA) test was used. The significance level was taken as a $p$-value $\leq 0.05$. Pearson correlation was employed between ACR and different stages of diabetic retinopathy.

The receiver operating characteristics (ROC) curve was plotted at different cut-offs between ACR and retinopathy by clinical examination of the retina (fundoscopy findings) taken as a gold standard, and the area under the curve (AUC) was calculated. A $2 \times 2$ table was constructed to determine sensitivity, specificity, positive and negative predictive values, positive and negative likelihood ratios, and total accuracy.

\section{RESULTS}

A total of 386 participants who were known patients of type II DM and on treatment for at least six months. Out of the $386(100 \%)$ cases, $239(62 \%)$ were males, and 147 (38\%) were females. The mean age was $57.48 \pm 9.51$ years, with most of the patients $(73.1 \%)$ $>50$ years of age.

Out of all (386) diabetic patients, 284 (73.6\%) had normal albuminuria i.e., ACR $<3(<3 \mathrm{mg} / \mathrm{mmol})$ and $102(26.4 \%)$ had microalbuminuria i.e., ACR 3-30 mg/ $\mathrm{mmol}$. The retinal changes in all patients with microalbuminuria (102) were severe non-proliferative diabetic retinopathy in $79(77 \%)$ patients and proliferative diabetic retinopathy in 23 (23\%) patients.

Mean \pm SD ACR levels $(\mathrm{mg} / \mathrm{mmol})$ among normal retina, mild to moderate NPDR, severe NPDR, and PDR were $1.49 \pm 0.35,2.67 \pm 0.21,13.07 \pm 3.65,26.48 \pm$ 2.27 , respectively as shown in table-IA. Furthermore, the ANOVA test resulted in significant differences within and between the groups $(p<0.05)$. This means that based on ACR, the stages of diabetic retinopathy can be differentiated (table-IB).

As ACR increased, the degree of retinal damage also increased, from mild to severe non-proliferative diabetic retinopathy and finally proliferative diabetic retinopathy. Pearson correlation analysis was perfor-

Table-IA: Comparison of albumin creatinine ratio between different stages of diabetic retinopathy.

\begin{tabular}{|c|c|c|c|c|c|}
\hline Parameters & $\begin{array}{c}\text { Normal } \\
\text { retina } \\
(\mathrm{n}=232)\end{array}$ & $\begin{array}{l}\text { Mild to moderate non- } \\
\text { proliferative diabetic } \\
\text { retinopathy }(n=52)\end{array}$ & $\begin{array}{c}\text { Severe non- } \\
\text { proliferative diabetic } \\
\text { retinopathy }(n=79)\end{array}$ & $\begin{array}{l}\text { Proliferative diabetic } \\
\text { retinopathy } \\
(n=23)\end{array}$ & $\begin{array}{c}p \text {-value } \\
\text { (combined) }\end{array}$ \\
\hline $\begin{array}{l}\text { Albumin } \\
\text { Creatinine ratio } \\
(\mathrm{mg} / \mathrm{mmol})\end{array}$ & $1.49 \pm 0.35$ & $2.66 \pm 0.20$ & $13.07 \pm 3.64$ & $26.47 \pm 2.27$ & $<0.001$ \\
\hline
\end{tabular}


Table-IB: Significance of albumin creatinine ratio between different stages of diabetic retinopathy.

\begin{tabular}{|c|c|c|c|c|c|c|}
\hline $\begin{array}{l}\text { Group } \\
\text { Comparison }\end{array}$ & $\begin{array}{l}\text { Normal Retina } \\
\text { vs } \\
\text { Mild to } \\
\text { moderate non- } \\
\text { proliferative } \\
\text { diabetic } \\
\text { retinopathy }\end{array}$ & $\begin{array}{c}\text { Mild to moderate } \\
\text { non-proliferative } \\
\text { diabetic } \\
\text { retinopathy Vs. } \\
\text { Severe non- } \\
\text { proliferative } \\
\text { diabetic } \\
\text { retinopathy }\end{array}$ & $\begin{array}{l}\text { Normal } \\
\text { retina } \\
\text { Vs. } \\
\text { Severe non- } \\
\text { proliferative } \\
\text { diabetic } \\
\text { retinopathy }\end{array}$ & $\begin{array}{l}\text { Mild to moderate } \\
\text { non-proliferative } \\
\text { diabetic } \\
\text { retinopathy } \\
\text { Vs. } \\
\text { Proliferative } \\
\text { diabetic } \\
\text { retinopathy }\end{array}$ & $\begin{array}{l}\text { Normal } \\
\text { retina } \\
\text { Vs. } \\
\text { Proliferative } \\
\text { diabetic } \\
\text { retinopathy }\end{array}$ & $\begin{array}{l}\text { Severe non- } \\
\text { proliferative } \\
\text { diabetic } \\
\text { retinopathy } \\
\text { Vs. } \\
\text { Proliferative } \\
\text { diabetic } \\
\text { retinopathy }\end{array}$ \\
\hline $\begin{array}{l}\text { Albumin } \\
\text { Creatinine ratio } \\
(\mathrm{mg} / \mathrm{mmol})\end{array}$ & $<0.001$ & $<0.001$ & $<0.001$ & $<0.001$ & $<0.001$ & $<0.001$ \\
\hline
\end{tabular}

med, which revealed a high correlation $(r=0.913)$ between ACR and stages of diabetic retinopathy (fig-1). Both renal and retinal micro-vascular complications correlated well in ACR range from $2-30 \mathrm{mg} / \mathrm{mmol}$. This indicated that ACR could be used as a screening marker for renal and retinal microvascular complications in patients with diabetes. However, at ACR $<2$ $\mathrm{mg} / \mathrm{mmol}$, we did not find a good correlation between renal and retinal microvascular complications. A statistically significant number of patients although had al-

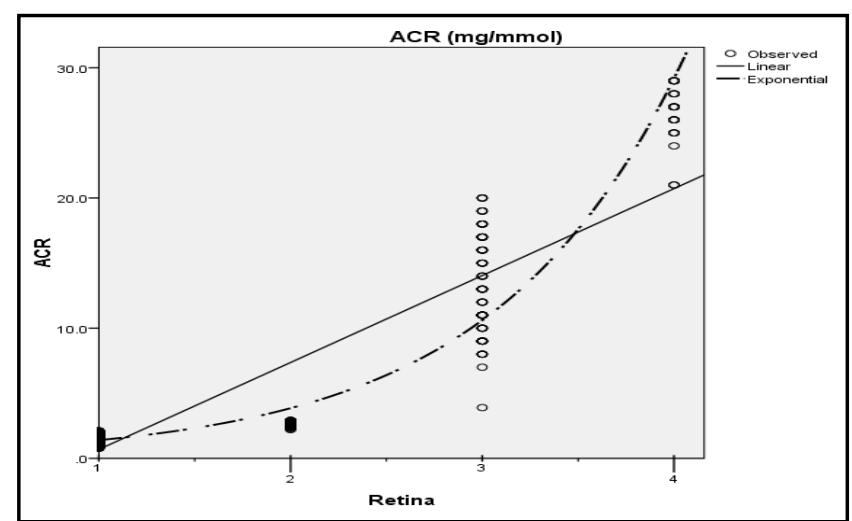

Figure-1: Correlation between albumin creatinine ratio (ACR) and retinopathy $(1=$ normal, $2=$ mild to moderate NPDR, $3=$ severe NPDR, 4=PDR).

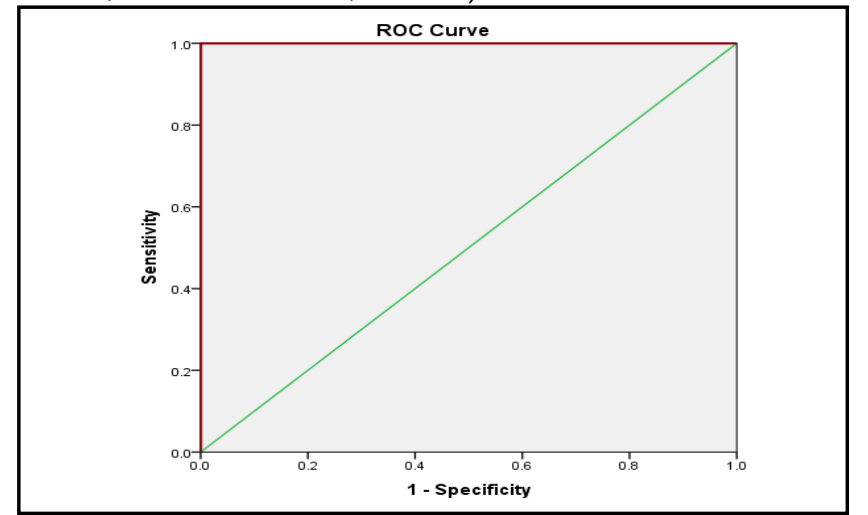

Figure-2: The receiver operating characteristics (ROC) curve between albumin creatinine ratio (ACR) and retinopathy and area under the curve (AUC). buminuria in normal range, but developed early retinal changes at ACR $<3 \mathrm{mg} / \mathrm{mmol}$. This showed that we need to lower the cut-off of ACR $<3 \mathrm{mg} / \mathrm{mmol}$ to enhance the sensitivity of this test to screen for early retinal complications in patients of DM.

The receiver operating characteristics (ROC) curve was plotted between ACR and the retinopathy on clinical examination as reference/gold standard at different cut-offs. For example, at cut-off $>2 \mathrm{mg} \mathrm{mmol}$ for ACR, we found the maximum area under the curve (AUC), i.e., 1.0, as shown in fig-2. At this cut-off, i.e. ACR $>2.0 \mathrm{mg} / \mathrm{mmol}, 2 \times 2$ table was constructed (tableII) and sensitivity \& specificity were calculated, shown in table-III.

Table-II: Diagnostic accuracy table between albumin creatinine ratio and retinal examination.

\begin{tabular}{l|c|c}
\hline \multirow{2}{*}{} & \multicolumn{2}{|c}{ Retinal examination } \\
\cline { 2 - 3 } & Yes/Positive & No/Negative \\
\hline Albumin Creatinine Ratio (mg/mmol) \\
\hline Yes/Positive & $154(52.7 \%)$ & $16(60 \%)$ \\
No/Negative & $0(47.3 \%)$ & $216(40 \%)$ \\
\hline
\end{tabular}

Table-III: Attributes of albumin creatinine ratio as diagnostic test (Cut-off $\geq 2.0 \mathrm{mg} / \mathrm{mmol}$ ).

\begin{tabular}{l|c}
\hline Diagnostic Parameters & Values \\
\hline $\begin{array}{l}\text { Sensitivity= True Positive/( True Positive } \pm \\
\text { False Negative) }\end{array}$ & $100 \%$ \\
\hline $\begin{array}{l}\text { Specificity= True Negative /(True Negative } \\
+ \text { False Positive) }\end{array}$ & $93.1 \%$ \\
\hline $\begin{array}{l}\text { Positive Predictive Value= True } \\
\text { Positive/(True Positive+ False Positive) }\end{array}$ & 1.0 \\
\hline $\begin{array}{l}\text { Negative Predictive Value= True } \\
\text { Negative/(True Negative +False Negative) }\end{array}$ & 0.90 \\
\hline $\begin{array}{l}\text { Diagnostic Accuracy=(True Positive +True } \\
\text { Negative)/All Patients }\end{array}$ & $95.5 \%$ \\
\hline
\end{tabular}

\section{DISCUSSION}

Our findings strongly suggest a link between ACR levels and the severity of DR in type-2 diabetes. During the progression from mild to severe non-proliferative diabetic retinopathy to proliferative diabetic retinopathy, our results showed increased retinal damage with an increase in ACR levels11,13-16. Romero- 
Arco et al, have established that urinary ACR has a higher association than eGFR with diabetic retinopathy ${ }^{17}$. Lee $e t$ al, have not only established an association between DR and ACR but have also proposed $2.26 \mathrm{mg} /$ mmol as the optimal cut-off value of ACR for predicting $\mathrm{DR}^{18}$.

Both DR and DKD are microvascular manifestations of diabetes that have comparable pathophysiological causes. Chronic hyperglycemia is expected to cause microvascular alterations in the retina and glomerulus, followed by the narrowing and final blockage of the vascular Lumina. The mechanisms that cause DR to advance are the same as those that cause vascular dysfunction. ACR is being used in monitoring DKD, whereas DR is mainly monitored by clinical examination. However, ACR can also be utilized to screen and monitor DR as it is used for DKD. ACR $<3 \mathrm{mg} /$ mmol is considered normal albuminuria while monitoring DKD. In our study, a statistically significant number of patients of DM were normal albuminuric, but still developed early retinal changes at ACR $<3$ $\mathrm{mg} / \mathrm{mmol}$. The cut-off for screening of DR was found to be slightly lower i.e., $2.0 \mathrm{mg} / \mathrm{mmol}$. In patients with type-2 diabetes mellitus, keeping the ACR cut-off at 2.0 $\mathrm{mg} / \mathrm{mmol}$ the monitoring of DR can be done through ACR instead of fundoscopy. Patients having ACR $\leq 2.0$ $\mathrm{mg} / \mathrm{mmol}$ would not need any intervention rather regular follow up by including ACR test. Still, the patients with abnormal ACR $(>2.0 \mathrm{mg} / \mathrm{mmol})$ may need intervention in their lifestyle or medication for better control of diabetes.

$\mathrm{ACR}$ as a screening marker for DR is more convenient and less subjective than clinical ophthalmic examination. A lot of work is being done in utilizing artificial intelligence for monitoring $\mathrm{DR}^{19-22}$. There are some potential challenges in implementing these technologies in healthcare ${ }^{23}$. However, combining ACR and artificial intelligence can enhance screening sensitivity, enabling early detection and control of DR.

\section{Disclosure}

One of the authors, Muhammad Aneeq Haroon, presented this article at the $27^{\text {th }}$ European Diabetes Congress on June 20-21, 2018 in Rome, Italy. Its abstract was published in the Journal of Diabetes \& Metabolism (26) and is available online (ISSN: 2155-6156). Therefore, there are no potential conflicts of interest for the authors in this work.

\section{CONCLUSION}

According to our findings, the severity of diabetic retinopathy can be biochemically monitored on the basis of albumin creatinine ratio. With a cut-off of ACR $\geq 2.0 \mathrm{mg} / \mathrm{mmol}$, patients with early diabetic retinopathy can be reliably differentiated from the healthy retina and followed up for further progression of the disease.

\section{CONFLICT OF INTEREST}

This study has no conflict of interest to be declared by any author.

\section{REFERENCES}

1. Matsushita K, Coresh J, Sang Y, Chalmers J, Fox C, Guallar E, et al. Estimated glomerular filtration rate and albuminuria for prediction of cardiovascular outcomes: a collaborative meta-analysis of individual participant data. Lancet Diabetes Endocrinol 2015; 3(7): 514-25.

2. American Diabetes Association Clinical Practice Recommendations. Diabetes Care 2001; 24(1): S1-133.

3. Keane WF, Eknoyan G. Proteinuria, albuminuria, risk, assessme$\mathrm{nt}$, detection, elimination (PARADE): a position paper of the National Kidney Foundation Am J Kidney Dis 1999; 33(5): 1004-10.

4. Improving global outcomes (KDIGO) CKD work group, KDIGO clinical practice guideline for the evaluation and management of chronic kidney disease. Kidney Int Suppl 2013; 3(2): S6-308.

5. O'Sullivan ED, Doyle A. The clinical utility of kinetic glomerular filtration rate. Clin Kidney J 2017; 10(2): 202-208.

6. Yoon HE, Kim ES, Mo EY, Shin SJ, Moon SD, Han JH. High normal albuminuria is associated with arterial stiffness and carotid atherosclerosis in Korean patients with type 2 diabetes. Nutr Metab Cardiovasc Dis 2015; 25(8): 787-94.

7. Handelsman Y, Bloomgarden ZT, Grunberger G, Umpierrez G, Zimmerman RS, Bailey TS, et al. American association of clinical endocrinologists and american college of endocrinology - clinical practice guidelines for developing a diabetes mellitus comprehensive care plan. Endocr Pract 2015; 21(Suppl-1): 1-87.

8. American diabetes association. Standards of medical care in diabetes: position statement. Diabetes Care 2016; 39(1): S4-S119.

9. Romero AR, Fernandez SR, Mateu AV, Alamo SR, Ribas AM. Changes observed in diabetic retinopathy: eight-year followup of a Spanish population. Br J Ophthalmol 2016; 100 (10): 1366-71.

10. Writing committee for the diabetic retinopathy clinical research network. Panretinal photocoagulation vs intravitreous ranibizumab for proliferative diabetic retinopathy: a randomized clinical trial. J Am Med Assoc 2015; 314(20): 2137-46.

11. Rani PK, Raman R, Gupta A, Pal SS, Kulothungan V, Sharma T. Albuminuria and diabetic retinopathy in type 2 diabetes mellitus sankara nethralaya diabetic retinopathy epidemiology and molecular genetic study (SN-DREAMS, report 12). Diabetol Metab Syndr 2011; 3(1): 9-12.

12. Mumtaz SN, Fahim MF, Arslan M, Shaikh SA, Kazi U, Memon MS. Prevalence of diabetic retinopathy in Pakistan; A systematic review. Pak J Med Sci 2018; 34(2): 493-500.

13. Chen YH, Chen HS, Tarng DC. More impact of microalbuminuria on retinopathy than moderately reduced GFR among type 2 diabetic patients. Diabetes care 2012; 35(4): 803-808.

14. Boelter MC, Gross JL, Canani LH, Costa LA, Lisboa HR, Três GS, et al. Proliferative diabetic retinopathy is associated with microalbuminuria in patients with type 2 diabetes. Braz J Med Biol Res 2006; 39(8): 1033-39.

15. Manaviat MR, Afkhami M, Shoja MR. Retinopathy and microalbuminuria in type II diabetic patients. BMC Ophthalmol. 2004; 4(2): 9-12 
16. Chang $\mathrm{CH}$, Chuang LM. Microalbuminuria and diabetic retinopathy in type 2 diabetic patients: From risk association to risk prediction. J Diabetes Investig 2013; 4(1): 42-44.

17. Romero-Aroca P, Baget-Bernaldiz M, Navarro-Gil R, MorenoRibas A, Valls-Mateu A, Sagarra-Alamo R, et al. Glomerular filtration rate and/or ratio of urine albumin to creatinine as markers for diabetic retinopathy: a ten-year follow-up study. J Diab Res 2018; 2018(2): 5637130.

18. Lee MK, Han KD, Lee JH, Sohn SY, Hong OK. Normal-to-mildly increased albuminuria predicts the risk for diabetic retinopathy in patients with type 2 diabetes. Sci Rep 2017; 7(1): 11757-62.

19. Flower MJ. Microvascular and macrovascular complications of diabetes. Clin Diab 2008; 26(2): 77-82.
20. Padhy SK, Takkar B, Chawla R, Kumar A. Artificial intelligence in diabetic retinopathy: A natural step to the future. Indian J Ophthalmol 2019; 67(7): 1004-1009.

21. Gunasekeran DV, Ting DSW, Tan GSW, Wong TY. Artificial intelligence for diabetic retinopathy screening, prediction and management. Curr Opin Ophthalmol 2020; 31(5): 357-65.

22. Li Z, Keel S, Liu C, He Y, Meng W, Scheetz J, et al. An automated grading system for detection of vision-threatening referable diabetic retinopathy on the basis of color fundus photographs. Diabetes Care 2018; 41(12): 2509-16.

23. Grzybowski A, Brona P, Lim G, Ruamviboonsuk P, Tan GSW, Abramoff $\mathrm{M}$, et al. Artificial intelligence for diabetic retinopathy screening: a review. Eye (Lond) 2020; 34(3): 451-60. 